\title{
EVALUASI PROGRAM MAN MODEL SEBAGAI UPAYA PENINGKATAN MUTU MADRASAH ALIYAH
}

\author{
Oleh: Abmad Darmadji*
}

\section{Abstract}

The study aims to highlight the program impact of Development of Madrasah Aliyah Project (DMAP) through MAN (read: Madrasah Aliayh Negeri) Model for improving Madrasah Aliyah. The study was carried out in MAN Yogyakarta III (Mayoga) with qualitative approach. The data collection is through documentation, interview, observation, and open questionnaire.

The study found that the DMAP program has been able to improve the output quality of the $M A N$ Model indicated by the percentage increase of acceptance in state universities, i.e. $34.21 \%$ during DMAP and $46.83 \%$ after DMAP. In addition, students of MAN Model are able to obtain achievement as those of from Favorite Senior High School (read: SMA Unggulan).



يهدف هذا البحث إلى الكشف عن أثر تطبيق برنامج تطوير المدارس الثانوية الدينية (المدارس العالية) عبر " نموذج المدرسة الثانوية الدينية " على مستوى الجودة الكلي للمدرسة. يعد هذا البحث دراسة لحالة المدرسة الثانوية الدينية رقم 3 في محافظة جوكجاكرتا، وذلك باستخدام منهج كيفي، عبر أدوات لجمع البيانات شملت الدراسة الوثائقية، والمقابلات الشخصية، والملاحظة واستمارات الاستبيان المفتوحة. توصلت الدراسة إلى أن برنامج تطوير المدارس الثانوية الدينية قد بنح في رفع مستوى الجودة الكلي للمدرسة محل الدراسة. يتضح هذا الارتفاع في مستوى الجودة عبر متابعة 




Keywords: MAN Model, Peningkatan Mutu, dan Madrasah Aliyah

\section{A. Pendahuluan}

Madrasah Aliyah (MA) adalah sekolah berciri khas Islam yang diselenggarakan oleh Departemen Agama (Depag) dan merupakan bagian dari sistem pendidikan nasional. ${ }^{1} \mathrm{MA}$ bertujuan menyiapkan siswa agar dapat melanjutkan pendidikan yang lebih tinggi, mampu mengembangkan diri sejalan dengan perkembangan ilmu pengetahuan dan teknologi dan seni yang dijiwai ajaran Islam, serta menjadi anggota masyarakat yang berhubungan secara timbal-balik dengan lingkungan sosial, budaya, dan alam sekitar yang dijiwai suasana keagamaan. ${ }^{2}$

Pada satu sisi betapa besar harapan yang digantungkan MA, namun di sisi lain dalam menjalankan misinya sejumlah tantangan harus dihadapi, antara lain perubahan orientasi pendidikan masyarakat dari "belajar untuk mencari ilmu" menjadi "belajar untuk mencari kerja". Satu kenyataan bahwa pelayanan pendidikan MA pada umumnya lebih rendah dibanding sekolah lain. Akibatnya, masyarakat lebih memilih sekolah selain MA. Untuk itu, MA dituntut meningkatkan pelayanan. ${ }^{3}$

Persepsi negatif masyarakat terhadap MA antara lain dilihat dari indikator mutu berikut: 1) aktifitas guru dan siswa; 2) kreatifitas guru dan siswa; 3) relasi guru dan siswa; dan 4) moralitas guru dan siswa. ${ }^{4} \mathrm{MA}$ belum mampu menunjukkan kualitas output yang menggembirakan dilihat dari nilai rata-rata hasil UAN MA

1 Surat Keputusan Mendikbud No. 0489/U/1992 dan Undang-Undang No. 20/2003 tentang Sistem Pendidikan Nasional.

2 Peraturan Pemerintah No. 29 tahun 1990 pasal 3 ayat 1 serta Kepmendikbud pasal 1 butir 6 No. 0489/U/1992.

3 Arif Furchan, Transformasi Pendidikan Islam di Indonesia: Anatomi Keberadaan Madrasah dan PTAI, (Yogyakarta: Gama Media, 2004), hal. 49

4 Zaini Hemi, "Persepsi Masyarakat Terhadap Mutu Pendidikan Madrasah Sebagai Pendidikan Islam”, Thesis, (Yogyakarta: PPs UIN Sunan Kalijaga Yogyakarta, 2004), hal. iv. 
secara nasional—baik negeri maupun swasta lebih rendah dibandingkan dengan nilai output SMU, ${ }^{5}$ termasuk di wilayah Provinsi DIY.

Guna peningkatan mutu MA, Depag membentuk klaster madrasah negeri model yang diharapkan memimpin pembangunan madrasah lainnya serta berperan sebagai agent of change menjadi madrasah berkualitas. ${ }^{6}$ Untuk tujuan tersebut, mulai tahun 1999 Depag mengembangkan Madrasah Aliyah Negeri (MAN) Model melalui Development of Madrasah Aliyah Project (DMAP). Satu dari 35 MAN Model adalah MAN Model Yogyakarta yaitu MAN Yogyakarta III (Mayoga). ${ }^{7}$

Sejalan dengan kebijakan dibentuknya MAN Model ini, juga dibentuk pusat sumber belajar bersama (PSBB) atau Common Learning Resource Centre (CLRC) yang merupakan lembaga fungsional baru yang berada dalam manajemen MAN Model. Lembaga ini merupakan pusat pendidikan dan latihan, dan pusat layanan bagi peningkatan kualitas akademik dan profesi para guru dan tenaga kependidikan lainnya. Melalui berbagai program kegiatan yang dirancang bersama Madrasah Development Centre (MDC) terbuka kesempatan bagi setiap guru untuk mengaktualisasikan kemampuan profesionalnya dengan memanfaatkan berbagai fasilitas pendidikan yang ada di PSBB ini. ${ }^{8}$

Pembentukan MAN Model sebagai upaya peningkatan mutu pendidikan madrasah perlu ditindaklanjuti. Namun, sebelumnya perlu untuk dilakukan evaluasi guna memperoleh data dan informasi memadai yang diperlukan, sehingga tindak lanjut upaya perbaikan dan peningkatan mutu pendidikan tetap terus dilakukan secara berkesinambungan sesuai dengan kondisi dan kebutuhan yang ada.

Sejauh yang penulis ketahui, evaluasi terhadap upaya pengembangan MA melalui MAN Model khususnya di MAN Model Yogyakarta belum pernah dilakukan dalam bentuk penelitian evaluasi yang cukup mendalam dan komprehensif. Dalam konteks inilah penelitian evaluasi pada MAN Model Yogyakarta ini dipandang perlu dilakukan.

5 Departemen Agama RI, Education of Management Information System (EMIS) Depag RI, (Jakarta: Dirjen Bagais Depag RI, 2005a).

Ahmad Malik Fadjar, Madrasah dan Tantangan Modernitas, (Bandung: Mizan, 1998), hal. 82.

7 Lampiran SK Dirjen Bagais Nomor E IV/PP.006/Kep/17-A/98 tentang Penetapan Sejumlah MAN menjadi MAN Model.

8 Departemen Agama RI, Pedoman Umum Pengembangan dan Pengelolaan PSBB, (Jakarta: Dirjen Bagais Depag RI, 2002c), hal. 2. 
Penelitian ini hendak mengungkap latar belakang Mayoga menjadi MAN Model, mengetahui kondisi Mayoga sebelum pemberlakuan DMAP, gambaran program DMAP dalam perubahan bidang pengelolaan madrasah, proses pembelajaran serta profesionalitas guru, sekaligus faktor pendukung dan penghambatnya.

\section{B. Metode Penelitian}

Penelitian ini dimaksudkan untuk mengungkap efektifitas program DMAP melalui penetapan status MAN Yogyakarta III sebagai MAN Model melalui penelitian evaluasi dengan pendekatan kualitataif. ${ }^{9}$ Model evaluasi yang digunakan adalah model Stake yang selain menekankan description and judgement, juga membedakan tiga fase dalam evaluasi program: antecedent, transaction dan outcome. ${ }^{10}$

Pengumpulan data dilakukan dengan teknik kajian dokumentasi, wawancara serta observasi. Analisis data dilakukan sepanjang penelitian ${ }^{11}$ dengan tahapan: analisis saat dan setelah pengumpulan data serta penyajian data secara sistematik yang dilakukan dengan tiga alur: reduksi data, display data dan penarikan kesimpulan atau verifikasi yang dilanjutkan dengan evaluasi sesuai dengan kriteria yang ditetapkan.

\section{Hasil Penelitian dan Pembahasan}

\section{Mayoga Sebelum Menjadi MAN Model}

Mayoga merupakan MAN alih fungsi dari Pendidikan Guru Agama Negeri (PGAN), sehingga Mayoga lebih muda dibanding MAN Yogyakarta I dan II, kendati bukan MAN termuda di DIY. Saat ditetapkan sebagai MAN Model, Mayoga bukan MAN terbaik, kendati bukan pula MAN terburuk di mana output yang melanjutkan pendidikan ke jenjang perguruan tinggi tidak lebih 20\%.

Jumlah siswa baru Mayoga setiap tahun rata-rata hanya tiga kelas. Kecilnya pendaftar dipengaruhi banyak hal, antara lain munculnya beberapa SMAN baru, Mayoga dianggap kurang strategis serta faktor kultur masyarakat sekitar.

9 Patton, How to Use Qualitative Methods in Evaluation, (London: SAGE Publications Ltd, 1987), hal. 9.

10 Worthen and Sanders, Educational Evaluation: Theory and Practice, (Worthington, Ohio: Charles A. Jones Publishing Company, 1989), hal. 113.

11 Nasution, Metode Penelitian Naturalistik/kualitatif, (Bandung: Tarsito, 1988), hal. 98. 
Kepemimpinan dan pengelolaan Mayoga masih menganut manajemen sekolah konvensional. Prinsip penempatan guru sesuai dengan kebutuhan dan keahlian belum berjalan dengan baik, bahkan masih terdapat "guru titipan" bukan karena dibutuhkan.

Sarana pendidikan Mayoga hanya "peninggalan" PGA sampai akhirnya mendapat fasilitas dari DMAP. Namun Mayoga berpotensi untuk dikembangkan, antara lain karena Mayoga mempunyai tanah yang lebih luas untuk mengembangkan sarana pendukung seperti fasilitas PSBB, asrama serta kemungkinan dibentuk madrasah terpadu (MIN, MTsN dan MAN). Potensi ini menjadi pertimbangan Kanwil Depag DIY sehingga diusulkan menjadi MAN Model.

\section{Pondasi MAN Model yang Tak Terlalu Kokoh}

Keberadaan Mayoga belum dikenal masyarakat, karena masyarakat luas lebih mengenalnya sebagai PGA. Pengenalan masyarakat luas terhadap lembaga terjadi karena kualitas lembaga tersebut di mata masyarakat. Hal demikian belum terjadi terhadapMayoga sebelum menjadi MAN Model.

Rendahnya prestasi akademis siswa Mayoga dipandang sebagai problem besar. Penyebabnya antara lain banyak warga madrasah yang masih mendikotomikan ilmu pengetahuan umum dan ilmu keagamaan. Keduanya dianggap mempunyai tingkat urgensitas berbeda. Terhadap ilmu umum, ada anggapan sebagai ilmu yang fardlu kifayah di mana tidak harus setiap orang menguasai bidang itu, sementara terhadap ilmu keagamaan menganggapnya fardlu 'ain yang harus dikuasai oleh setiap orang. Akibatnya, kesungguhan mereka mempelajarai keduanya menjadi berbeda. Padahal, rendahnya prestasi akademis siswa MA inilah salah satunya yang menyebabkan rendahnya favoritas masyarakat terhadap MA.

Rendahnya prestasi akademis siswa MAN/MAS juga karena kurikulum MA yang dianggap terlalu sarat materi. Semula komposisi pendidikan umum dan agama bagi MA adalah 70:3012 namun dengan keluarnya UU No. 2 Tahun 1989 tentang Sisdiknas yang memposisikan MAN/MAS adalah SMU berciri khas Islam, maka MA harus memberikan materi kurikulum minimal sama dengan materi di SMA. Dengan demikian, saat ini komposisi umum dan agama 
menjadi 100:30, dengan perbandingan materi pelajaran MA dan SMA adalah 130:100. Di sisi lain hal itu menjadi 'kelebihan' bagi MA, namun masyarakat tidak melihatnya sebagai suatu kelebihan.

Kondisi Mayoga yang kurang membanggakan, bukan mutlak kesalahan internal, namun lebih karena menjadi korban sistem yang ada mengarah pada kurang adilnya perhatian pemerintah terhadap MAN dan madrasah lainnya. Ini terbukti antara lain adanya Surat Edaran Mendagri No. 903/ 2429/SJ/2005 tentang Pedoman Penyusunan APBD yang melarang pemerintah daerah mengalokasikan APBD kepada organisasi vertikal-termasuk MAN/ MAS karena di bawah naungan Depag, maka subsidi pemda terhambat dengan surat edaran tersebut.

Beberapa cara yang patut dipertimbangkan dalam memecahkan problem besar di atas antara lain dengan mengasramakan siswa atau diintegrasikan dengan pondok pesantren. MAN di tengah pesantren atau beberapa MAN yang menerapkan sistem boarding school terbukti mampu menjalankan cara ini secara produktif, salah satunya seperti MAN Insan Cendikia. Selain itu dengan membenahi metode pembelajaran, meningkatkan mutu guru, atau melengkapi sarana dan fasilitas belajarnya. Ketiganya dilakukan secara terintegrasi agar lebih produktif. Cara ini pula yang ingin dicapai DMAP dengan segala program MAN Model termasuk di Mayoga.

\section{Mewujudkan Madrasah Unggul}

Visi MAN Model Yogyakarta adalah membentuk siswa unggul, terampil, dan berkepribadian matang (ULTRA PRIMA), ${ }^{13}$ sedangkan misinya adalah 1) menyelenggarakan pendidikan yang berbudaya keunggulan, kreatif dan inovatif; 2) membekali siswa dengan life skill baik general life skill maupun specific life skill; 3) memadukan penyelenggaraan program pendidikan umum dan kejuruan; dan 4) menghidupkan pendidikan ber-ruh Islam, menggiatkan ibadah, memperteguh keimanan dan akblaqul karimab sehingga memperoleh output yang ULTRA PRIMA. ${ }^{14}$

Visi dan misi di atas dijabarkan dalam indikator dan strategi pencapaiannya. Visi unggul dan terampil dijabarkan masing-masing dalam sembilan (9) indikator, sementara visi berkeperibadian matang ditunjukkan dengan 14

13 Dokumen MAN Model Yogyakarta, 2000.

14 Notulensi Workshop dan Lokakarya Mayoga, Agustus 2000. 
indikator. ${ }^{15}$ Secara operasional, dituangkan dalam rencana strategis (Renstra) MAN Model Yogyakarta 1999-2008: empat tahun pertama (1999-2003) dan empat tahun kedua (2004-2008). Renstra ditindaklanjuti dengan program jangka panjang dan program tahunan perbidang: bidang kurikulum dan pengajaran, kesiswaan, keuangan dan sarana prasarana, perpustakaan serta pembinaan profesi guru dan karyawan. Program dirancang bersama pusat sumber belajar bersama (PSBB) dan pusat pengembangan madrasah (PPM) yang meliputi program akademik, ekstrakurikuler hingga penggalian dana mandiri. ${ }^{16}$

\section{Inovasi Kurikulum MAN Model Yogyakarta}

MAN Model Yogyakarta melakukan inovasi kurikulum dengan pengaturan ulang alokasi waktu antara kurikulum Depdiknas, Depag, dan Kurikulum Mayoga yang ditetapkan sebagai Kurikulum MAN Model untuk mencerminkan gagasan comprehensive school (program akademik dan vocasional). Sistem pengajaran bersifat fleksibel dan adaptif serta relevan dengan tuntunan masyarakat. Hanya membuka jurusan IPA dan IPS dan penjurusan dilakukan sejak kelas 2 (XI) sejak tahun 2000.

Penguasaan bahasa asing dilakukan dengan penambahkan mata pelajaran conversation dan mulhadatsah. Muatan lokal berupa: conversation, pengembangan penalaran dan minat baca (PPMB) dan Bahasa Jawa. Dibentuk 5 rumpun mata pelajaran: agama, bahasa, IPA, IPS dan Korsen (ketrampilan, olah raga dan seni). Selain itu dibuka 2 program: program pengembangan potensi akademik (P3A) bagi siswa yang berminat melanjutkan pendidikan ke PT dan program pengembangan hidup mandiri (PPHM) bagi siswa lainnya. Jurusan IPA PPHM disediakan ketrampilan teknisi komputer atau industri meubeler, sedangkan bagi jurusan IPS PPHM disediakan tata busana dan batik. Peserta PPHM berhak mendapat sertifikat keterampilan dari Disnakertrans Propinsi DIY bagi yang memenuhi standar.

Pelajaran olahraga dan seni hanya wajib memilih satu cabang sesuai dengan minat dan bakat siswa, dan diarahkan pada olahraga/seni prestasi yang dilaksanakan sore hari dan dibina oleh pelatih profesional. Tabel berikut contoh gambaran perbandingan kurikulum inovasi Mayoga dan Kurnas.

15 Rumusan Akhir Penjabaran Strategi Pencapai Visi Mayoga, 2002.

16 Departemen Agama RI, Pedoman Umum Pengembangan dan Pengelolaan Madrasab Model, (Jakarta: Dirjen Bagais Depag RI, 2002c), hal. 10. 
Tabel Perbandingan Setruktur Kurikulum Nasional dan Kurikulum Inovasi Kelas 2

\begin{tabular}{|c|c|c|c|c|c|c|c|}
\hline \multirow{3}{*}{$\begin{array}{c}\mathrm{N} \\
\mathrm{O}\end{array}$} & \multirow{3}{*}{ Mata Pelajaran } & \multicolumn{3}{|c|}{ Jurusan IPA } & \multicolumn{3}{|c|}{ Jurusan IPS } \\
\hline & & \multirow{2}{*}{$\begin{array}{l}\text { Kur. } \\
\text { Nas }\end{array}$} & \multicolumn{2}{|c|}{ Kur MAN Model } & \multirow{2}{*}{$\begin{array}{l}\text { Kur. } \\
\text { Nas }\end{array}$} & \multicolumn{2}{|c|}{ Kur MAN Model } \\
\hline & & & P3A & PPHM & & $\mathrm{P} 3 \mathrm{~A}$ & PPHM \\
\hline 1 & Al-Qur'an Hadits & 2 & 2 & 2 & 2 & 2 & 2 \\
\hline 2 & Figh & 2 & 2 & 2 & 2 & 2 & 2 \\
\hline 3 & Aqidah Akhlaq & 1 & 1 & 1 & 1 & 1 & 1 \\
\hline 4 & Sejarah Kebud. Islam & - & - & - & - & - & - \\
\hline 5 & Kewarganegaraan & 2 & 2 & 2 & 3 & 2 & 2 \\
\hline 6 & Bahasa \& Sastra Ind. & 3 & 4 & 3 & 3 & 6 & 4 \\
\hline 7 & Bahasa Inggris & 4 & 4 & 4 & 4 & 6 & 6 \\
\hline 8 & Bahasa Arab & 2 & 2 & 1 & 2 & 2 & 2 \\
\hline 9 & Matematika & 5 & 6 & 4 & 4 & 2 & 2 \\
\hline 10 & Kesenian & 2 & 2 & 2 & 2 & 2 & 2 \\
\hline 11 & Pend. Jaskes* & 2 & 2 & 2 & 2 & 2 & 2 \\
\hline 12 & Sejarah & 2 & 1 & 1 & 3 & 2 & 1 \\
\hline 13 & Geografi & - & 1 & 1 & 2 & 1 & 1 \\
\hline 14 & Ekonomi & - & - & - & 5 & 10 & 7 \\
\hline 15 & Sosiologi & - & - & - & 4 & 4 & 2 \\
\hline 16 & Fisika & 5 & 6 & 4 & - & - & - \\
\hline 17 & Kimia & 4 & 4 & 4 & - & - & - \\
\hline 18 & Biologi & 5 & 6 & 4 & - & - & - \\
\hline 19 & Tek. Infokom & 2 & 2 & 2 & 2 & 2 & 2 \\
\hline 20 & Conversation** & - & 2 & - & - & 2 & - \\
\hline 21 & PPMB & - & 2 & - & - & 2 & - \\
\hline 22 & Keteramp. Tata Busana & - & - & - & - & - & 12 \\
\hline 23 & $\begin{array}{l}\text { Keteramp. Meubeler atau } \\
\text { Teknisi Komputer }\end{array}$ & - & - & 12 & - & - & - \\
\hline 24 & PKL & - & - & - & - & - & - \\
\hline 25 & Kewirausahaan & - & - & - & - & - & - \\
\hline 26 & Try out & - & - & - & - & - & - \\
\hline & Jumlah & 43 & 48 & 48 & 41 & 48 & 48 \\
\hline
\end{tabular}

Sumber: Dokumentasi Kaur Kurikulum dan Pengajaran MAN Model , 2001

Kendala bidang kurikulum antara lain kurikulum masih disikapi secara kaku sehingga mengekang kreativitas dan inovasi. Kurikulum MAN masih belum mencerminkan kesinambungan dari kurikulum MTs/SLTP, sejumlah mata pelajaran masih test oriented dan belum terintegrasikan dengan materi life skill sehingga program keterampilan dianggap hanya pelengkap, kendala birokratis, serta supervisi kurikulum. ${ }^{17}$

Kurikulum memiliki posisi sentral dalam setiap upaya pendidikan. Kurikulum MAN Model merupakan kurikulum yang diposisikan untuk

17 Dokumen Kaur Bidang Kurikulum dan Pengajaran MAN Model, 2005. 
menyelesaikan masalah sosial pendidikan dimana pengembangan bangsa dijadikan dasar untuk mengembangkan kehidupan masa depan. Pendekatan pengembangan kurikulum yang dipilih adalah the grass root model dan bukan top-down the administrative model. Orientasi pendidikan tidak lagi pada having tetapi being, ${ }^{18}$ bukan schooling tetapi learning, ${ }^{19}$ dan bukan hanya transfer of knowledge tetapi membangun jiwa melalui transfer of values lewat keteladanan. ${ }^{20}$

\section{Pengelolaan dan Kepemimpinan Kepala MAN Model}

Secara operasional MAN Model Yogyakarta mempunyai badan legislasi sebagai mitra kerja dan pengawas berupa Majlis Madrasah (komite sekolah). ${ }^{21}$ Fungsinya sebagai penentu kebijakan umum madrasah dan lembaga pengendali penyelenggaraan pendidikan dari segi akademik, administrasi maupun keuangan.

Pengelolaan Mayoga dilakukan kolektif antara Kepala dan Wakil Kepala dibantu enam kepala urusan dan TU. Terdapat BPUM, BP/BK dan team TI yang bertanggung jawab langsung kepada Kepala Madrasah. Masukan kebijakan bisa berasal dari Dewan Penyantun Madrasah, Majlis Madrasah dan PSBB. Tugas pokok Kepala MAN Model adalah menyelenggarakan pendidikan dan pengajaran secara umum, termasuk fungsi administrator, fungsi pemimpin dan manajer pendidikan. ${ }^{22}$ Ditetapkan tugas pokok dan kewenangan Kepala MAN juga tanggungjawab pengelola di bawahnya. ${ }^{23}$

Selama lima tahun (1998/1999-2004/2005) menjadi MAN Model, Mayoga mengalami tiga kali pergantian pimpinan yang ketiganya mempunyai pola kepemimpinan dan pengelolaan tersendiri. Gaya kepemimpinan formal konvensional (berpatokan pada juklak juknis) ditunjukkan Kepala MAN Model pertama, sedangkan kepala MAN Model yang kedua tidak formalistik, low

18 Silberman, Active Learning: 101 Cara Belajar Siswa Aktif, (Bandung: Nuansa, 2004), hal. 11.

19 Tileston, Teaching Strategies for Active Learning, (Thousand Oaks, California: Corwin Press, Inc., 2007), hal. 22.

20 Knight, Filsafat Pendidikan: Isu-isu Kontemporer \& Solusi Alternatif, terj. Mahmud Arief, (Yogyakarta: Idea-l Press, 2004), hal. 106.

21 Bush, Theories of Educational Management, (London: Paul Chapman Publishing, 1986), hal. 48-50.

22 Sallis, Total Quality Management in Education, (Philadelphia: Cogan Page, 1993), hal. 89.

23 Notulensi Lokakarya Internal Mayoga, Agustus 2000 di Kaliurang. 
profile dan sangat friendly dengan bawahannya, sementara yang ketiga tetap mempertahankan brand image yang telah dibangun oleh kepala MAN sebelumnya dengan menggeser fokus utama pada bidang akademis.

Kebijakan otonomisasi pendidikan dengan diterapkannya TQM dan MBS merupakan good will pemerintah untuk memperbaiki kondisi pendidikan. MBS pada hakikatnya adalah penyerasian sumber daya yang dilakukan secara mandiri oleh madrasah dengan melibatkan semua kelompok kepentingan (stake holder) yang terkait dengan madrasah secara langsung dalam proses pengambilan keputusan untuk memenuhi kebutuhan peningkatan mutu ${ }^{24}$ atau untuk mencapai tujuan pendidikan nasional. Konkretnya, manajemen madrasah tidak lagi terpusat dari atas baik dari Depag maupun Depdiknas, tetapi berpusat di madrasah.

Organisasi madrasah laksana sebuah mesin, bila sehat maka akan memiliki budaya organisasi yang positip dan proses organisasi yang efektif. ${ }^{25}$ Dalam mewujudkan budaya madrasah yang baru, diperlukan konsolidasi ideal berupa reaktualisasi doktrin agama yang selama ini mengalami pendangkalan dan penyempitan makna. Konsep tentang ikhlas, jihad, dan amal shaleh, perlu direaktualisasikan maknanya dan dijadikan core values dalam pengelolaan MAN. Dengan landasan nilai fundamental yang kokoh, menjadikan MAN memiliki modal sosial (social capital) yang sangat berharga dalam membangun rasa saling percaya, kasih sayang, keadilan, komitmen, dedikasi, kesungguhan, kerja keras, persaudaraan dan persatuan. Lembaga MAN juga perlu tampil dengan nama, semangat, semboyan dan performen baru. Itulah tampaknya yang mendorong MAN Model Yogyakarta mengambil motto madrasatî jannatî (sekolahku adalah surgaku).

Diperlukan Kepala MAN Model yang visioner dan transformasional yang mampu melakukan proses prerubahan dan mentransformasikan semua wagra madrasah agar mau berubah dan meningkatkan dirinya, yang di dalamnya melibatkan motif dan pemenuhan kebutuhan serta penghargaan terhadap para bawahan. ${ }^{26}$ Setidaknya terdapat empat faktor untuk menuju

24 Murphy \& Beck, School-based Management as School Reform, (California: Corwin Press, 1995), hal. 13. Lihat pula Bonstingl, Quality of School, (California: Corwin Press, 2001), hal. 9-10.

25 Reddin, Managerial Effectiveness, (New York: McGraw-Hill Book Company, 1996), hal. 289.

26 Vilstern, "Leadership in school" dalam Adrie J. Visscher, Managing School Toward High Performance, Linking School Management Theory to the School Effectiveness Knowledge Best, (Netherland: Swets and Zeitlinger, 1999), hal. 179. 
kepemimpinan tranformasional: idealized influence, inspirational motivation, intellectual stimulation, dan individual consideration. Menampilkan kepemimpinan transformasional dapat lebih menunjukkan sebagai seorang pemimpin yang efektif dengan hasil kerja yang lebih baik. Karenanya, satu keuntungan jika kepala MAN dapat menerapkan kepemimpinan transformasional di madrasahnya.

Harapan akhir MAN Model selain memberikan imbas perubahan yang lebih baik kepada MAN/MAS lain, secara internal terwujud menjadi madrasah atau sekolah unggul. Sekolah unggul seringkali disamakan dengan sekolah efektif yang setidaknya mempunyai 11 karakter, yaitu: kepemimpinan yang profesional, visi dan tujuan bersama, lingkungan belajar, konsentrasi pada pembelajaran, harapan yang tinggi, pengayaan yang positif, pemantauan kemajuan, hak dan tanggung jawab peserta didik, pengajaran penuh makna, organisasi pembelajar, dan kemitraan keluarga-sekolah. ${ }^{27}$

\section{Penguatan Kapasitas Sumber Daya Manusia (SDM)}

Awal penetapan MAN Model (1998/1999), SDM yang ada sebanyak 69 orang (PNS: 39 dan honorer 30 orang), meliputi guru, seorang laboran dan sejumlah staf TU di mana sebagian ditugaskan sebagai pengelola perpustakaan. Penambahan sejumlah tenaga dilakukan atas dasar kebutuhan, kendati secara kuantitas tidak terjadi penambahan secara signifikan. Sementara kualifikasi guru berdasarkan jenjang pendidikan dan golongan kepangkatan, sejak tahun 1998/1999 sampai 2004/2005 mengalami perkembangan, di antaranya tahun 2001/2002 enam orang sudah menyelesaikan S2 dan tahun 2005 mencapai delapan orang.

Peningkatan kapasitas tenaga mendapat perhatian yang besar sehingga terdapat Kaur Pembinaan Profesi Guru (PPG). Salah satu tugas utamanya adalah menyelenggarakan pelatihan untuk peningkatan kemampuan akademik guru.Beberapa cara dilakukan guna meningkatkan kualifikasi dan kapasitas SDM MAN Model. Pada awal DMAP lima orang guru mengikuti pendidikan guru bina dan sejumlah guru mengikuti pendidikan magister. Peningkatan kapasitas tenaga juga dilakukan melalui berbagai seminar, lokakarya dan pelatihan rutin yang sifatnya internal MAN Model Yogyakarta (pertemuan reboan).

27 Harris, School Improvement: What's in it for School?, (New York: Routledge Falmer, 2002), hal. 86-87. 
Dampak program di atas cukup signifikan terhadap kinerja guru. Guru merasa leluasa dalam mengaktualisasikan idealismenya ketika melaksanakan proses pembelajaran, karena guru berkewenangan penuh selama pembelajaran. Guru tidak lagi tergantung juklak-juknis, dapat berkreasi dan berinovasi tanpa takut dipersalahkan.

\section{Perpustakaan, Ruang Workshop Keterampilan dan Laboratorium}

Fungsi perpustakaan sekolah adalah sebagai pusat kegiatan belajarmengajar, pusat penelitian siswa dan pusat buku-buku rekreatif. Ketiga fungsi tersebut akan tergambar dalam koleksi perpustakaan bersangkutan. ${ }^{28}$ Fungsi ini telah diwujudkan Perpustakaan MAN Model sejak dipindah ke lokasi yang strategis dan refresentatif, baik dari sisi tempat yang nyaman (ber-AC), jumlah koleksi dan fasilitas pendukung yang memadai hingga sistem pelayanan yang menyenangkan.

Sejak tahun 2003 sudah disediakan layanan Internet bagi pengguna perpustakaan dan tahun 2007 dilakukan katalogisasi on-line, pembangunan area baca dan diskusi terbuka (ABADIKA) dengan hot-spot jeringan internet. ${ }^{29}$ Penambahan fasilitas cukup memberikan pengaruh yang signifikan bagi masyarakat madrasah dan masyarakat umum pengguna. Perpustakaan tidak hanya sebagai sumber belajar, namun juga sebagai tempat pembelajaran, khususnya di ruang referensi.

Pasca DMAP, perpustakaan terus meningkatkan program dan pelayanan yang tersusun dalam bentuk Renstra 5 Tahun Perpustakaan Mayoga tahun 2006/2007-2010/2011. Program unggulannya antara lain adalah lomba resensi buku baru, pendampingan Mayoga Book Lover, pemilihan the best reader dan gerakan wakaf buku (GWB) Mayoga. Pelayanan perpustakaan setiap hari kerja pukul 07.00-16.30 WIB selain kepada civitas madrasah juga kepada masyarakat umum. Tahun 2007 berhasil meraih perpustakaan terbaik pertama tingkat Nasional kategori perpustakaan sekolah tingkat SMA dan SMK.

Laboratorium merupakan sarana pendidikan dan pembelajaran yang penting karena dapat membantu pemahaman siswa terhadap materi pelajaran. Saat menjadi MAN Model, beberapa laboratorium dibangun 
dengan dana DMAP, antara lain laboratorium bahasa, biologi, fisika, kimia, IPS, PAI, matematika dan laboratorium komputer. Siswa mengakui bahwa pembelajaran lebih efektif dan nyaman ketika sarana laboratorium lebih memadai.

\section{Input dan Output MAN Model Yogyakarta}

Siswa merupakan salah satu imput MAN. Penerimaan siswa baru sebelum menjadi MAN Model hanya tiga kelas (A, B dan C), tahun 1999/2000 empat kelas dan berikutnya berturut-turut lima dan enam kelas sampai penelitian ini dilakukan. Besarnya calon siswa baru kadang menjadi indikasi besarnya animo dan kepercayaan masyarakat terhadap suatu lembaga. Berbagai cara dilakukan untuk menjaring calon siswa yang berkualitas, namun menghadapi kendala, antara lain faktor kultur masyarakat yogyakarta yang secara umum bukanlah masyarakat santri, munculnya beberapa SMA Negeri baru, dan letak MAN Model yang tidak terlalu strategis dibanding MAN lain.

Indikator kualitas output suatu sekolah antara lain dilihat dari persentase kelulusan, nilai EBTA/EBTANAS/UAN yang dicapai dan jumlah output yang diterima di PTN. Dalam rentang 1997/1998-2007/2008, kelulusan mencapai $100 \%$ terjadi pada tahun 1997/1998, 2000/2001 dan 2001/2002, terendah terjadi tahun 2003/2004 dengan hanya 94,9\%, sementara tahun lainnya rata-rata $99,4 \% .^{30}$

Dua tahun sebelum DMAP (1997/1998-1998/1999) keluaran yang diterima di PTN rata-rata hanya 19,20\%, sementara saat berlangsungnya DMAP (1999/ 2000-2003/2004) meningkat menjadi 34,21\% dan tiga tahun pasca DMAP (2004/ 2005-2006/2007) meningkat lagi mencapai 46,83\%. Peningkatan tersebut antara lain ditunjang meningkatnya kapasitas guru dan tenaga kependidikan, memadainya sumber dan media pembelajaran serta meningkatnya kualitas proses pembelajaran.

\section{Pusat Sumber Belajar Bersama (PSBB) MAN Model Yogyakarta}

PSBB merupakan lembaga fungsional dalam manajemen MAN Model sebagai laboratorium sarana layanan bagi peningkatan kemampuan profesional guru dan tenaga kependidikan lainnya untuk mendukung peran MAN Model dalam peningkatan kualitas MA. Sejak awal pendiriannya (1999) hingga 2008, 
PSBB dibagi dua periode. Pertama, masa pembangunan sarana prasarana (19992003) dengan struktur pengelola ketua, wakil ketua, sekretaris dan bendahara. Pelatihan sudah dilakukan meskipun masih terbatas bagi tenaga internal. Kedua, periode 2004-2008, struktur PSBB terdiri dari pembina, penanggung jawab, pengelola, pelaksana dan kelompok nara sumber, staf pengajar dan instruktur. ${ }^{31}$ PSBB juga dilengkapi dengan guru bina dan guru inti yang ditetapkan dengan SK Kepala MAN Model Yogyakarta. Dilakukan beberapa kegiatan dengan sasaran internal MAN Model dan MAN/MAS lainnya seperti orientasi KBK, pelatihan penyusunan instrumen evaluasi, MGMP 7 mata pelajaran yang diUAN-kan.

Bidang garapan dan program kegiatan PSBB MAN Model Yogyakarta selama tahun 2004-2008 secara garis besar terdiri dari bidang: 1) diklat, 2) pemantapan kelembagaan; 3) pengembangan SDM; 4) pengembangan fasiliitas; 5) pengembangan keuangan; 6) pemasaran; 7) layanan masyarakat dan properti dan 8) penelitian dan pengembangan. Bidang-bidang di atas dijabarkan dalam renstra dan program tahunan. ${ }^{32}$

Berdasarkan pengukuran kinerja, program peningkatan kapasitas SDM (guru) secara kuantitas tidak seluruhnya mencapai target 100\%. Hal ini terjadi karena masih terdapat sejumlah MAN/MAS yang sepertinya setengah hati untuk mengirimkan utusan peserta serta kendala jarak yang relatif jauh dari Mayoga. Kendati demikian terdapat pula yang melampauai target seperti peserta MGMP bidang studi yang di-UAN-kan.

\section{Kiprah Pusat Pengembangan Madrasah (PPM)}

PPM merupakan lembaga semi otonom dan nonstruktural di bawah Kanwil Depag Provinsi yang berfungsi sebagai lembaga pemikir untuk peningkatan kualitas madrasah dan pesantren. PPM Kanwil Depag Provinsi DIY dibentuk 10 Oktober 2003.33

Visi PPM adalah menjadikan madrasah dan pesantren lembaga berkualitas, mandiri dan unggul dalam persaingan. ${ }^{34}$ Visi PPM DIY adalah terwujudnya pusat pengkajian dan pengembangan pada madrasah dan pondok pesantren

31 Keputusan Dirjen Bagais No. DJ.II/281B/02.

32 Rencana Strategis (Renstra) PSBB MAN Model Yogyakarta 2004-2008.

33 Surat Keputusan (SK) Kaknwil Depag DIY No. W1/1/PP.00.11/1845.a/2003.

34 Departemen Agama RI, Pedoman Umum Pengelolaan Pusat Pengembangan Madrasab (PPM), (Jakarta: Dirjen Bagais Depag RI, 2002b), hal. 4-5. 
di Provinsi DIY yang terpercaya dan dambaan umat. Misinya adalah menjadikan madrasah dan pondok pesantren sebagai lembaga pendidikan Islam yang unggul dalam pengembangan moral spiritual dan ilmu pengetahuan dan teknologi (Iptek). ${ }^{35}$

Sebagai sebuah institusi yang berperan penting dalam pengembangan sejumlah lembaga, maka pola koordinasi dan tata kerja yang baik merupakan kunci utama berfungsinya lembaga ini. PPM merekomendasi pengembangan dan perbaikan kepada Badan Diklat, kepada PSBB dan kepada MAN Model. Peran dan fungsi pemberian masukan itu efektivitasnya menjadi tidak optimal ketika pembentukannya di daerah justru dilakukan setelah lembaga-lembaga mitra kerjanya eksis lebih dahulu (MAN Model dan PSBB dibentuk tahun 1998/1999 dan proyeknya berakhir tahun 2003/2004, sementara PPM baru dibentuk tahun 2003).

Banyak pihak berharap pada kiprah PPM karena memiliki SDM yang sangat berkompeten di bidangnya. Akan tetapi disayangkan ketika SDM tersebut adalah orang-orang yang sangat sibuk pada institusinya sehingga tidak cukup waktu untuk menjalankan tugas dan perannya di PPM, akibatnya peran maupun fungsinya tidak optimal, bahkan ada kesan hanya sebatas sampingan, karena idealnya rekomendasi PPM kepada PSBB atau MAN Model hasil kajian dan penelitian yang komprehensif. PPM ke depan sebaiknya ditangani serius dengan menugaskan personal yang bukan hanya sebagai tugas tambahan.

\section{Penutup}

Sebelum menjadi MAN Model, Mayoga bukanlah MAN terbaik kendati bukan pula terburuk. Pengelolaannya masih sentralistik dan berorientasi pada juklak-juknis. Prestasi akademis siswa rendah dan keberhasilan dalam seleksi pendidikan lanjutan tidak lebih dari $20 \%$ setiap tahunnya. Namun di sisi lain Mayoga memiliki potensi berupa satu lokasi dengan MTsN dan MIN yang dapat dikembangkan menjadi madrasah terpadu serta memiliki tanah yang luas untuk mengembangkan fasilitas MAN. Potensi ini menjadi dasar penetapan Mayoga menjadi MAN Model.

Program-program DMAP diterjemahkan dalam visi misi MAN Model Yogyakarta berupa membentuk siswa dan output yang 'unggul, terampil dan

35 Kantor Wilayah Departemen Agama Provinsi DIY, Profil Kantor Wilayah Departemen Agama Provinsi DIY, hal. 187. 
berkepribadian matang (ULTRA PRIMA)', yang operasionalnya dituangkan dalam rencana strategi 4 tahunan dan program kerja tahunan. Pencapaian visi diawali dengan perubahan struktur kelembagaan dan pengelolaan, peningkatan sumber daya manusia dan inovasi kurikulum. DMAP menekankan pengelolaan MAN Model pada orientasi total quality management (TQM) atau total quality assurance (TQA) dan total quality control (TQC) dengan menerapkan school based manegement (SBM).

Kendati output Mayoga belum tergolong siswa unggul, namun persentase yang diterima di PTN/PTS saat DMAP berlangsung (1999/2000-2003/2004) mencapai $34,21 \%$ dan 46,83\% tiga tahun pasca DMAP (2004/2005-2006/2007). Sejumlah siswa berhasil dalam lomba siswa berprestasi bidang akademik dan non-akademik padahal input siswanya bukan termasuk input unggulan. Dengan demikian input "biasa" dapat menjadi output yang "luar biasa".

Secara kelembagaan, usaha perubahan dan perbaikan bagi MAN/MAS di sekitar Mayoga difasilitasi oleh PSBB. Selain lembaga pendidikan dan latihan, PSBB juga sebagai laboratorium sarana pelayanan kegiatan akademik. PSBB didukung sumber daya dan dana yang relatif memadai serta idealnya bersinergi dengan Pusat Pengembangan Madrasah (PPM) Kanwil Depag DIY, namun hal itu tidak/belum terjadi karena PPM kurang berfungsi secara optimal.

\section{DAFTAR PUSTAKA}

Bonstingl, J.J. 2001. Quality of School. California: Corwin Press.

Bush, T. 1986. Theories of Educational Management. London: Paul Chapman Publishing.

Departemen Agama RI. 2002a. Pedoman Umum Pengembangan dan Pengelolaan Madrasah Model. Jakarta: Dirjen Bagais Depag RI.

- 2002b. Pedoman Umum Pengelolaan Pusat Sumber Belajar Bersama (PSBB). Jakarta: Dirjen Bagais Depag RI.

. 2005. Education of Management Information System (EMIS) Depag RI. Jakarta: Dirjen Bagais Depag RI.

Dokumen Bagian Akademik dan Kurikulum MAN III Yogyakarta, 1997/1998 - 2007/ 2008. 
Dokumen MAN Model Yogyakarta, 2000.

Dokumen Kaur Bidang Kurikulum dan Pengajaran MAN Model, 2005.

Dokumen Perpustakaan MAN Model dan Observasi, 2007.

Dokumen Rencana Strategis (Renstra) PSBB MAN Model Yogyakarta 2004-2008.

Dokumen Rumusan Akhir Penjabaran Strategi Pencapai Visi Mayoga, 2002.

Fadjar, A.M. 1998. Madrasah dan Tantangan Modernitas. Bandung: Mizan.

Furchan, A. 2004. Transformasi pendidikan Islam di Indonesia: Anatomi keberadaan Madrasah dan PTAI. Yogyakarta: Gama Media.

Guba, E.G \& Lincoln, Y. S. 1989. Naturalistic inquiry. Beverley Hills: Sage Publication. Harris, A. 2002. School improvement: What's in it for school? New York: Routledge Falmer.

Hassan. 1988. Evaluasi Kurikulum. Jakarta: Dirjen Dikti Depdikbud.

Kantor Wilayah Departemen Agama Provinsi DIY. 2005. Profil Kantor Wilayah Departemen Agama Provinsi DIY. Yogyakarta: Kanwil Depag DIY.

Keputusan Menteri Pendidikan dan Kebudayaan (Kepmendikbud) Nomor 0489/ $\mathrm{U} / 1992$.

Knight, G.R. 2004. Filsafat Pendidikan: Isu-isu Kontemporer \& Solusi Alternatif, terj. Mahmud Arief. Yogyakarta: Idea-lPress.

Murphy, J. \& Beck, L.G. 1995. School-Based Management as School Reform. California: Corwin Press.

Notulensi Workshop dan Lokakarya Internal Mayoga, Agustus 2000.

Patton, M.Q. 1987. How to use qualitative methods in evaluation. London: SAGE Publications Ltd.

Peraturan Pemerintah. 1990. Nomor 29, Tahun 1990, tentang Pendidikan Menengah.

Reddin, W.J. 1970. Managerial Effectiveness. New York: McGraw-Hill Book Company.

Sallis, E. 1993. Total Quality Management in Education. Philadelphia: Cogan Page.

Shaleh, A.R. 2004. Madrasah dan Pendidikan Anak Bangsa: Visi, Misi dan Aksi. Jakarta: Raja Grafindo Persada. 
Silberman, M.L. 2004. Active Learning: 101 Cara Belajar Siswa Aktif. Bandung: Nuansa. Surat Keputusan Dirjen Bagais Nomor E IV/PP.006/Kep/17-A/98 tentang MAN Model.

Surat Keputusan Kaknwil Depag DIY No. W1/1/PP.00.11/1845.a/2003.

Surat Keputusan Menteri Pendidikan dan Kebudayaan Nomor 0489/U/1992.

Tileston, D.W. 2007. Teaching Strategies for Active Learning. Thousand Oaks, California: Corwin Press, Inc.

Undang-undang Nomor 20, Tahun 2003, tentang Sistem Pendidikan Nasional.

Vilstern, C.A.V. 1999. “Leadership in school” dalam Adrie J. Visscher, Managing School toward High Performance, Linking School Management Theory to The School Effectiveness Knowledge Best. Netherland: Swets and Zeitlinger.

Wohlstetter, P. 1994. "Model of high performance" dalam Susan Albert Mohrman, S.A. (at all)., School-Based Management. San Francisco: Jossey Bass.

Worthen, B.R. and Sanders, J.R. 1989. Educational Evaluation: Teory and Practice. Worthington, Ohio: Charles A. Jones Publishing Company.

Zaini Hemi. 2004. Persepsi Masyarakat terbadap Mutu Pendidikan Madrasah sebagai Pendidikan Islam. Thesis Magister, tidak diterbitkan. Yogyakarta: PPs UIN Sunan Kalijaga Yogyakarta.

Zamroni. 2000. Paradigma Pendidikan Masa Depan. Yogyakarta: Publishing. 